\section{Determinants of choosing a foreign brand in emerging economy: lessons and implication for the local entrepreneurs}

Foreign brand in emerging economy

\author{
Md. Abdul Momen \\ East West University, Dhaka, Bangladesh \\ Seyama Sultana \\ United International University, Dhaka, Bangladesh \\ Farhana Ferdousi \\ East West University, Dhaka, Bangladesh, and \\ Shamsul Huq Bin Shahriar \\ American \& Efird Bangladesh Ltd, Dhaka, Bangladesh
}

Received 25 January 2021 Revised 6 March 2021 Accepted 3 April 2021

\begin{abstract}
Purpose - It is evident that the local small and medium enterprises of Bangladesh suffered in the competition because of the strong presence of foreign brands in the market. The purpose of this study is to figure out the factors influencing consumers to purchase a foreign brand predominantly among young consumers.

Design/methodology/approach - It is a quantitative study considering 257 young demographics as respondents. They are drawn randomly. Confirmatory factor analysis, regression analysis and a path model of structural equation model using AMOS graphics software are used in this study to analyze the data.

Findings - This study finds two out of three identified variables are influencing the foreign product purchase for the young Bangladeshi consumers. Brand value and product features of the given foreign product are the most dominant factors behind this adoption. However, a significant relationship between product quality and brand choice is not evident in this study.

Research limitations/implications - It will give a clue to the small or medium startup of the country that normally target the young customer but face challenges to understand their mind and sometimes lagging because of the strong presence of the international brands.

Originality/value - A comprehensive review of the literature suggests that not so many studies took place that determines the respective factors behind the purchase of foreign brands particularly among young demographics of a lower middle income developing nation.
\end{abstract}

Keywords Consumer behavior, Foreign brands, Local entrepreneurs, Local brands

Paper type Research paper

(c) Md. Abdul Momen, Seyama Sultana, Farhana Ferdousi and Shamsul Huq Bin Shahriar. Published in Vilakshan - XIMB Journal of Management. Published by Emerald Publishing Limited. This article is published under the Creative Commons Attribution (CC BY 4.0) licence. Anyone may reproduce, distribute, translate and create derivative works of this article (for both commercial and noncommercial purposes), subject to full attribution to the original publication and authors. The full terms of this licence maybe seen at http://creativecommons.org/licences/by/4.0/legalcode 
$\mathrm{XJM}$

19,2

\section{Introduction}

In this competitive global marketplace, brands play a critical role in consumers' decisionmaking process and also provide a differential advantage to marketers. As consumers' brand awareness facilitates their decision-making (Macdonald and Sharp, 2000). Foreign brands are trying to be more customer-focused and responsive and, in this process, the internet has become their major tool in the global market place. Besides, due to the huge improvement in information and communications technology now consumers are more empowered, connected, informed and aware all around the world. Even in a lower middle income- developing country (will officially graduate by 2026) such as Bangladesh, consumers are virtually connected with the local and foreign brands and know literally everything about the products and offers through the internet, websites and Social Networking Sites (Momen et al., 2020). Furthermore, because of the high availability of international brands and products, consumers' ability to select foreign also has increased in the developing countries (Kashi, 2013). Therefore, customers' propensity toward foreign brands has also increased.

Because of easy entry mode foreign brands with already established product identity, appropriate market research, proper marketing and promotion strategy, high retail capacity and huge investment are creating an uncertain situation for the local small and medium entities in the market. Often, foreign brands are implementing promotional strategies to capture the emerging market. Things have become more complicated for the regional consumer trade entities for the new local entrepreneurs as well.

This study tends to focus on a specific question such as why consumers from any emerging economy or developing country look for foreign brands nowadays. The answer to this question can essentially help the local entrepreneurs and small brands to design better brand strategies. To figure out the answer, the researcher tried to figure out two underlying factors that cause the adoption of consumers for a particular brand preference. Similar to many other studies, Keller and Brexendorf (2019) paid much importance to the equity model behind the adoption of any brand, customers are supposed to be rationally and emotionally convinced. In the line with that product, image is considered as the foundation of this emotional connection with the customers whereas product features and product quality are the two major rational attributes that customers are always looking for behind any brand choice and adoption.

As there are few studies that highlights the factors influencing the buying to go for a foreign brand in choosing their daily goods. However, there are hardly any research that conceptualized the most contributing factors on the basis of comprehensive literature review from a developing nations' perspective. In the line with that this study is unique in nature to figure out the most relevant factors to determine the foreign product purchase from one of the fastest growing economies perspective (Rooney, 2019).

\section{Objective of the study}

This study aims to identify the key determinants of choosing foreign consumer brands from the perspective of Bangladeshi consumers. This study will help the regional trade entities to understand the brand perception of the local consumers, and it will provide some lessons to the local entrepreneurs and small brands to develop effective brand strategies for the particular market.

\section{Literature and conceptual framework}

The brand itself works as the key motivating factor to build a strong position in the local and international market. The brand expresses the personality of its users; foreign brands 
indicate status, provide experiences and stories to tell. In the case of a developing country, the emergence of international brands might harm regional business entities, local brands (both big and small) and entrepreneurs. Though some Bangladeshi brands known as "deshi" brands are doing also very well but, in most cases, entrepreneurs start their business operations with informal set-ups (Shahriar et al., 2019), and they implement the branding strategies through their entrepreneurial journey.

Furthermore, in any emerging market consumers are more vibrant so often it becomes very difficult to determine the nature of the market and its maturity, with increasing income ((Lee and Nguyen, 2017; Kashi, 2013) and changing lifestyle consumers look for innovations (Shankar and Narang, 2020) and variety, consequently, inexperienced marketers fail to implement responsive marketing strategies. Considering the scale and future growth of emerging markets foreign brands also try to build a strong position in these markets.

Advancement in information technology and globalization has provided customers wider options and opportunities to consider while purchasing any preferred products or services, hence, customers' preferences and perceptions of purchasing foreign products instead of locally available products might be shaped based on various criteria.

\subsection{Product feature}

According to Kashi (2013):

Consumers may intend to purchase a particular brand because they perceive the brand offers the right features, quality, or emotional benefits.

In reality, customers do not pay for the product but for the solution to their problems, features of the particular product which satisfy their needs and the emotional and physical benefit that the product offers at that specific time. However, in recent times the increase in global product variety has caused a multitude of customers' demand for any new product features (ElMaraghy et al., 2013). Product variety, different colors, shapes and sizes are the most dominant elements of the product features that attract customers to buy a foreign product (Haque et al., 2015).

One of the reasons for customers' preference toward foreign products and brands is the unavailability of the preferred features in local products. Often it seems that though the local industries of consumer products are much diverse but yet not diverse extensively or innovative enough; therefore, many customers who cannot satisfy their needs and wants through local products properly rely heavily on foreign brands or foreign products. Subsequently, gradually they develop kind of a fondness toward foreign brands and products, and even when local producers offer similar products, those customers are less likely to switch.

\subsection{Brand/product quality}

Some customers also tend to believe that foreign products are of premium quality compared to the local ones. Country of origin effect as well as less confidence on local merchandise and services or prior positive experience with foreign products helped formulation of such attitudes that lead customers to perceive foreign products and brands as premier and preferring their products instead of Bangladeshi products.

While exploring the Indian consumers' attitudes toward local and foreign brand names Kinra, (2006) also found that the quality of the foreign brands is perceived to be higher than the local brands. In a study Kashi (2013) surveyed 850 customers to explore the consumer purchase behavior of buying foreign brands in comparison to local brands; the findings
Foreign brand in emerging economy 
showed that consumers' need for uniqueness, perceived quality and emotional value directly influence the customers' purchasing intention.

In their study, Haque et al. (2015) mentioned that:

[.. .] Bangladeshi consumers pay much attention to the quality of foreign products. In the future, initiatives must be taken by marketers for informing the consumers about the superior quality of their products through advertisements.

Because of the strong presence of social media platforms, product and brand quality is being highly measured by the customers (Momen $e t$ al., 2020). They can now easily understand the quality with a different type of available online quality matrix and the comparison easily available online. In addition, customers can easily access the information of a brand such as ingredients, durability in a very easy way.

\subsection{Brand image}

On consumers' perception toward buying foreign brands, an important study was conducted by Dao and Heidt (2018), in their study they tried to understand why consumers from developing countries prefer foreign brands? They focused on the Vietnamese consumers' choice of buying two famous Japanese brands named Sony and Honda. They collected the required data from 400 Vietnamese consumers and found that when identifying with the developed nation consumers in developing countries prefer foreign brands from the developed countries over the domestic brands.

Customers' perceived social status or expressiveness attitude also shapes their perception toward foreign products and brands (Han, 2017). As it is usual in the Bangladeshi cultural perspective, lots of customers hold the belief that western products and brands are superior and contribute more to personal image development or in higher maintaining social status. This perceived fascination toward foreign brands and products which is perhaps associated with their social value confirmation influences those customers' perception biasedly toward foreign brands.

Foreign brands are considered as a threat to the local brands (Ali et al., 2017). Wellknown international brands with aggressive marketing strategies can easily capture the market; therefore, the increasing trend of international trade has created tension among the local entrepreneurs. Creating a brand identity is not a very easy task particularly for the small and informal business entities. Nevertheless, local brands and new entrepreneurs can learn many important lessons from foreign brands and their strategies.

In Figure 1, a hypothesized model shows the conceptual framework of the study. Based on the literature review, this study figures out the following three alternative hypotheses for the study to be tested:

(1) Product features have a significant impact on the choice of a foreign brand.

(2) Brand image has a significant impact on the choice of a foreign brand.

(3) Product quality has a significant impact on the choice of a foreign brand.

\section{Methodology}

This exploratory study adopts a quantitative research method. As the purpose of the study is to figure out the reasons why young demographics are choosing foreign brands in their daily product selection. A total of 257 young consumers in the emerging market were chosen as respondents randomly. Because of the pandemic of the COVID-19 situation, most of the data was collected online by using Google Forms. 


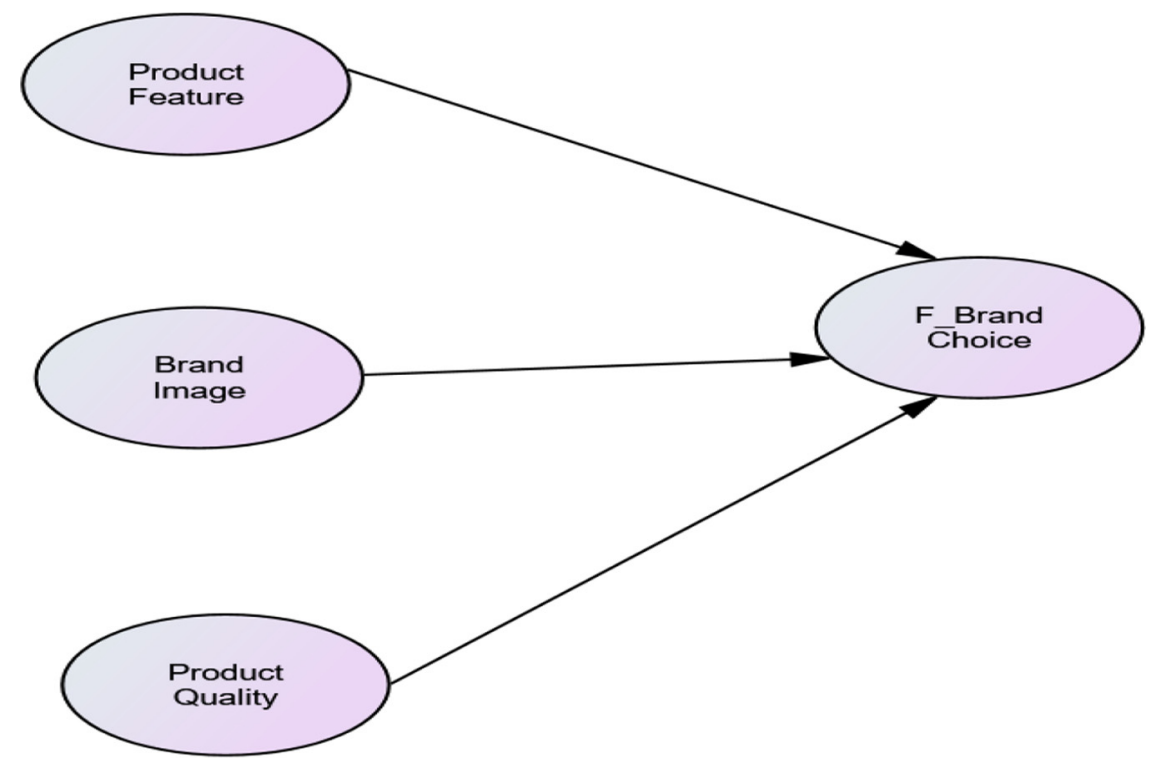

Foreign brand in emerging economy

A widely used scaling technique, namely, the five-point Likert scale is used in the questionnaire to give extensive options to the respondents (Malhotra et al., 2017). Confirmatory factor analysis (CFA) has been used to determine the respective items of each specific factor (Hair et al., 2017). To test the hypothesis, the regression weight of the path model of structural equation model using AMOS graphics is used.

\section{Data analysis}

With the use of factor analysis, Table 1 shows that KMO and Bartlett's test shows that the number of samples used in the study is adequate. It is well above the benchmark value of 0.70 .

\subsection{Confirmatory factor analysis}

Figure 2 that is CFA confirms the total three factors related to the foreign brand choice that is the dependent variable. Here, all the benchmark values for the goodness of the fit that CFI, RMSEA and significant value is within the acceptable range. Loading of items related to respective variables also confirms the higher association in the CFA.

KMO and Bartlett's Test

Figure 1. Conceptual framework 
$\mathrm{XJM}$

19,2

200

Figure 2.

Confirmatory factor analysis

\section{Normed Chi Square $=1.861$}

$\mathrm{P}=0.001$

$\mathrm{CFI}=0.960$

RMSEA $=0.058$

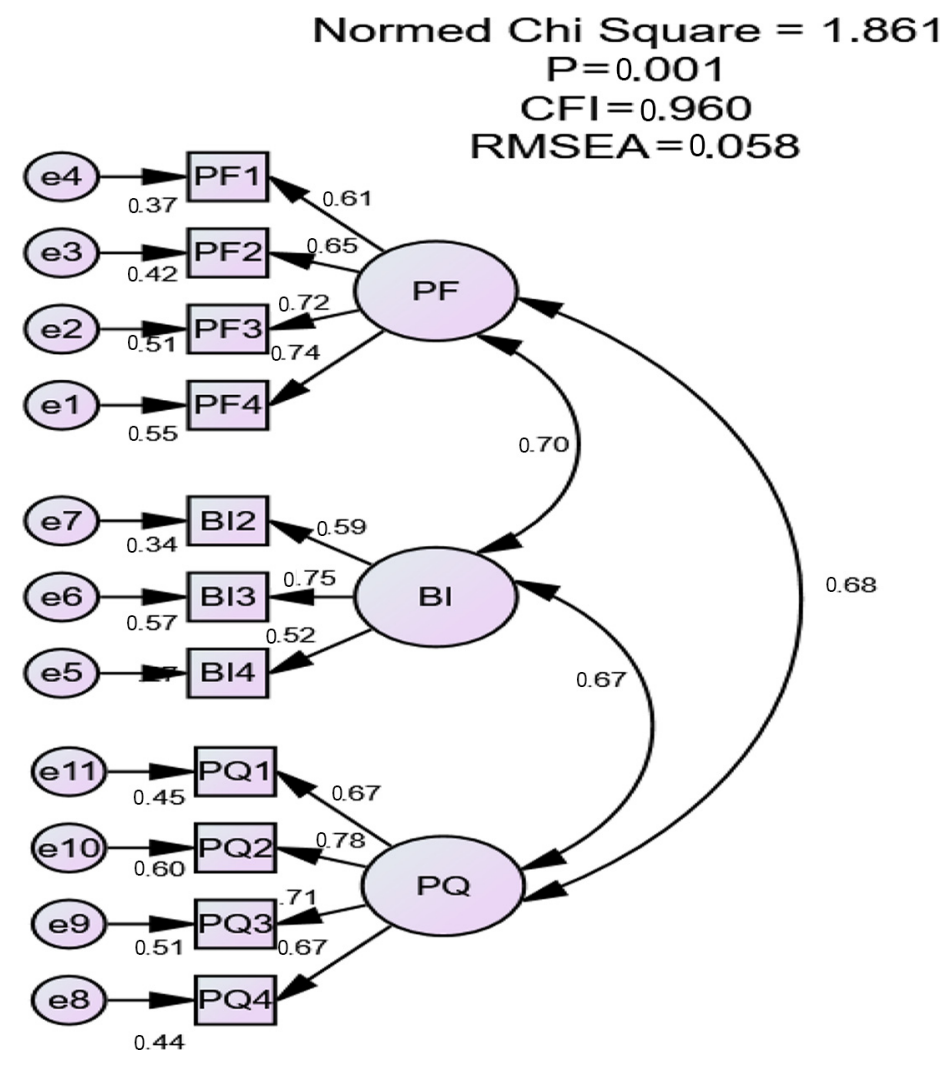

The Normed Chi-square in the figure with the respective chi-square and "P" statistic is less than the benchmark value of 5 shows that the model is overall fit (Momen et al., 2019). Herewith the value of CFI close to 1 shows the good fit in the baseline comparison of the model. In addition, RMSEA value less than 0.07 shows the better value in the composite index. Hence, in all the overall fit indexes, the present study meets all the requirements.

\subsection{Hypothesis testing}

Critical ratio (CR) value is used to test the derived hypothesis in the baseline or main model of SEM. Here, the benchmark CR value to signify the relationship is 1.96 (Hair et al., 2010). Figure 3 brings the path analysis that shows the relationship between and among the variables. The goodness of the fit of the model looks upright with all the values within the range of the benchmarks.

Table 2 shows that all the derived null hypothesis between the independent and dependent variable is rejected. Meaning that the relationship between product characteristics and brand choice, brand value and brand choice, product quality and brand choice was found significant in terms of foreign brand consumption in this study. 


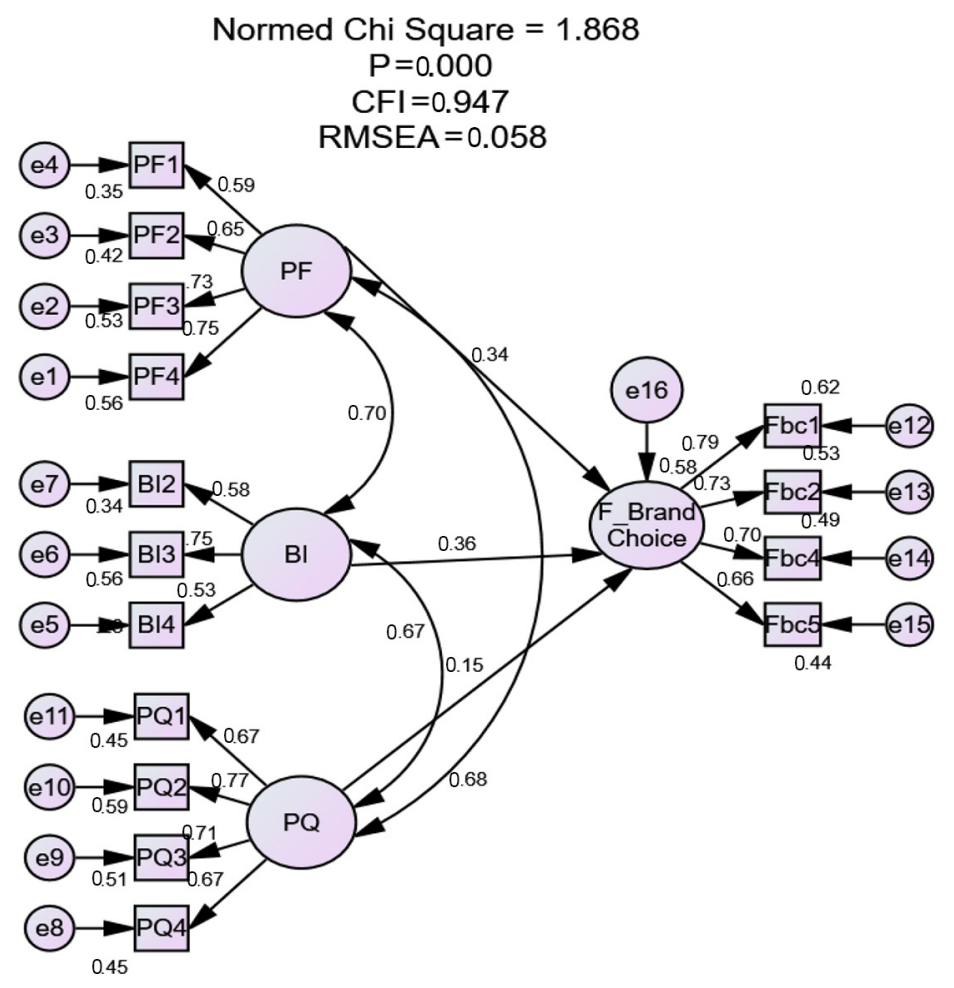

Foreign brand in emerging economy

Figure 3.

Path model using SEM

\begin{tabular}{|c|c|c|c|c|c|c|}
\hline & Estimate & S.E. & C.R. & $\mathrm{P}$ & Label & Tab \\
\hline F_Brand_Choice $\leftarrow$ PF & 0.364 & 0.126 & 2.885 & 0.004 & Sig & Regression weigl \\
\hline F_Brand_Choice $\leftarrow$ BI & 0.416 & 0.154 & 2.695 & 0.007 & Sig & (group number 1 \\
\hline F_Brand_Choice $\leftarrow$ PQ & 0.195 & 0.137 & 1.424 & 0.154 & Not Sig & default model) \\
\hline
\end{tabular}

\section{Research findings}

The research result is supported by the literature described in the literature review section. Product features and brand value are found the most significant factors behind the choice of a foreign brand among the young educated people of Bangladesh. It is also evident in the many studies that young people normally pay more attention to product features and brand value than other characters of the brand.

The result of this study is consistent with these studies. Besides, product features and variety are also found important among the young demographic of Bangladesh in choosing a foreign brand. However, as some studies argue, when brand image is dominant, sometimes consumers do not bother about the product quality. They consider it implied in a brand with a higher image. 
$\mathrm{XJM}$

19,2

202

\section{Discussion}

Bangladesh, a riverine country located in the northeastern corner of the Indian subcontinent. It is a democratic and secular country that has achieved socio-political stability in recent years with sustained economic growth. According to the report of the World Bank (2020), Bangladesh reduced its poverty from $43.8 \%$ (in 1991) to $14.8 \%$ (in 2016), based on the parameter of the international poverty line of $\$ 1.90$ a day, and in 2015 , it achieved the lowermiddle-income country status. As an emerging market with a population of around 160 million and sustainable macroeconomic performance in recent years, Bangladesh is also offering better prospects for investment; therefore, global brands are considering it as a new land of opportunities. Foreign brands with exposure and experience offer different value propositions to the emerging markets. In some cases, with a proper value chain, better market research and local focus foreign brands enjoy the benefits of monopolistic competition.

Consumers of emerging markets also look for better products and solutions and tend to expend more on foreign brands. Customers' favorable outlook toward foreign brands and foreign products and their tendency to purchase those lead to the country's various entrepreneurship opportunities and their exciting activities at inspection. While some entrepreneurs are using their business, strategies based on customers' such perception toward foreign brands and products, others are having a hard time keeping their business afloat because of customers' fondness for foreign products and brands instead of local ones. Some entrepreneurs believe customers are right to choose foreign brands and products as those are providing more innovative offerings and in present times, they match customers' requirements accurately. Respecting customers' positive perception toward foreign brands and products, these entrepreneurs developed their business or adapted their business strategies around the concept of providing customers with quality foreign products and making them familiar with renowned foreign brands. Entrepreneurs who are running ecommerce businesses, online shops, or entrepreneurs who are importers are reaping the benefit out of customers through their tendency of foreign product preference. These entrepreneurs are using the free trade policy and think that customers' increased preference of foreign brands and products are inevitable considering the globalization effects and global standards also, local industries of consumer products should evolve in line with international standards; otherwise, it is logical for the local industries to fall behind.

However, many entrepreneurs are suffering the worst because of customers' fondness toward foreign brands and products instead of local ones. Entrepreneurs who are trying to develop local brands and who are promoting locally made products are finding it quite difficult to establish their business because of customers' likeness biased likeness toward foreign products and brands. These entrepreneurs believe that customers overestimate foreign brands or products while underestimating the local brands and products, not giving them enough chance to prove themselves.

These phenomena lead young and new local entrepreneurs toward disappointing outcomes, as they are failing to attract customers toward their brands and products. As a result, the success of local entrepreneurship or development and the success of local brands are now questionable as they are often deemed unworthy by the consumers. Such victim entrepreneurs hope and believe that that though customers' such selective and biased perception is costing their business but the situation is likely to improve as customers' perception is slowly on the change and soon, they will realize the significance of buying local brands and products, as those are getting equal with foreign brands and products in terms of value and quality. 


\section{Lesson for local entrepreneurs}

In Bangladesh, similar to other developing nations, products range from first moving consumer items (FMCG) to shopping products, international brands are dominant in the market competition against their local counterparts. As described in the earlier phase of the study, the paper aims to extract the lessons for the local entrepreneurs. It gives them the clear direction; how should they design their business model and highlight the specific factors to compete the international competitors. For instance, from the regression weight of path model (Table 2), it is clear that Bangladeshi consumers who prefer foreign brands, they prioritize it because of the product features and brand image. However, it is clear in the model that quality of the local products in almost every aspect is quite competitive. This finding will assist the local entrepreneurs to strategies their future course of actions. They should not limit their product features and types into lower limit. Instead, further product designs and new types should be offered in the market according to the customer demands. The findings are supported by the other studies as well (Gulliando and Shihab, 2019). In addition, they should establish their brand image in the top of the customers' mind by following strategic brand building procedure with the continuous brand communication strategies (Novansa and Ali, 2017). If they will be able to do this, local brands of Bangladesh can be very competitive against their international counterparts.

\section{Conclusion and recommendation}

As foreign brands are dominant in the Bangladeshi consumer market, local entrepreneurs, particularly young startups, find it hard to compete with them. The study will give them a clear idea of what to focus on by detecting the reasons for buying foreign brands by the young Bangladeshi consumers. Instead of focusing on a lot of other issues, infant startups and local brands (both formal and informal) should highly focus on their brand-building activities and create emotional bonds with the target group.

Apart from that, in developing continuous improvement in the product features and design, they should not lag behind to develop and manage a sustainable image in the heart and mind of the customer. Government, local business associations and other relevant stakeholders can also consider these as an important takeaway to nurture the existing business under their control. Future research might take place where brand image can play a moderating role between the relationships of independent variables (such as product quality and features) and foreign brand choice in a given community.

\section{References}

Ali, A., Abu Hassim, A. and Farid, M.F.S. (2017), "Exploring factors attracting purchase intention of imported automobile among consumers' in Malaysia”, Asia Pacific Journal of Social Science Research, Vol. 2 No. 1, pp. 1-8.

Dao, K.N.T.H. and Heidt, T. (2018), "Why consumers in developing countries prefer foreign brands: a study of Japanese brands in Vietnam", Journal of Promotion Management, Vol. 24 No. 3, pp. 398-419, doi: 10.1080/10496491.2018.1378307.

ElMaraghy, H., Schuh, G., ElMaraghy, W., Piller, F., Schönsleben, P., Tseng, M. and Bernard, A. (2013), "Product variety management", CIRP Annals, Vol. 62 No. 2, pp. 629-652.

Gulliando, D. and Shihab, M.S. (2019), "The effect of product quality, price and promotion on the purchase decision of telkomsel service products", International Journal of Innovative Science and Research Technology, Vol. 4 No. 9, pp. 419-425.
Foreign brand in emerging economy

203 
$\mathrm{XJM}$

19,2

Hair, J.F., Hult, G.T.M., Ringle, C.M., Sarstedt, M. and Thiele, K.O. (2017), "Mirror, mirror on the wall: a comparative evaluation of composite-based structural equation modeling methods", Journal of the Academy of Marketing Science, Vol. 45 No. 5, pp. 616-632.

Han, J.S. (2017), "Effects of Brand image on purchase intention and brand loyalty: focused on mediating role of the brand trust", Culinary Science and Hospitality Research, Vol. 23 No. 2, pp. 135-145.

Haque, A., Anwar, N., Yasmin, F., Sarwar, A., Ibrahim, Z. and Momen, A. (2015), "Purchase intention of foreign products: a study on Bangladeshi consumer perspective”, SAGE Open, Vol. 5 No. 2, pp. 1-12.

Kashi, A.N. (2013), "Exploring consumer purchase behaviour: foreign versus local brands", Global Business Review, Vol. 14 No. 4, pp. 587-600.

Keller, K.L. and Brexendorf, T.O. (2019), "Measuring brand equity", Handbuch Markenführung, Springer Gabler, Wiesbaden, pp. 1409-1439.

Kinra, N. (2006), "The effect of country-of-origin on foreign brand names in the Indian market", Marketing Intelligence and Planning, Vol. 24 No. 1, pp. 15-30.

Lee, J. and Nguyen, M. (2017), "Product attributes and preference for foreign brands among Vietnamese consumers", Journal of Retailing and Consumer Services, Vol. 35, pp. 76-83, available at: https:// doi.org/10.1016/j.jretconser.2016.12.001.

Malhotra, N.K., Nunan, D. and Birks, D.F. (2017), Marketing Research: An Applied Approach, Pearson Education Limited.

Macdonald, E.K. and Sharp, B.M. (2000), "Brand awareness effects on consumer decision making for a common, repeat purchase product: a replication", Journal of Business Research, Vol. 48 No. 1, pp. 5-15, available at: https://doi.org/10.1016/S0148-2963(98)00070-8

Momen, M.A., Sultana, S. and Haque, A.K.M.A. (2019), "Web-based marketing communication to develop brand image and brand equity of higher educational institutions: a structural equation modelling approach, global knowledge", Global Knowledge, Memory and Communication, Vol. 69 No. 3, pp. 151-169.

Momen, M.A., Shahriar, S.H.B., Hassan, M.K. and Sultana, S. (2020), "Determinants of using social networking sites toward entrepreneurial success: experience from a developing nation", Emerging Economy Studies, Vol. 6 No. 2, pp. 191-200, available at: https://doi.org/10.1177/ 2394901520977425

Novansa, H. and Ali, H. (2017), "Purchase decision model: analysis of brand image, brand awareness and price (case study SMECO Indonesia SME products)", Saudi Journal of Humanities and Social Sciences, Vol. 2 No. 8, pp. 621-632.

Rooney, K. (2019), “Bangladesh's economy is soaring - here's why”, World Economic Forum, available at: https://www.weforum.org/agenda/2019/11/bangladesh-gdp-economy-asia/ (accessed 6 January 2021).

Shahriar, S.H.B., Arafat, S. and Alam, M.S. (2019), "Branding in informal sector: qualitative analysis from a developing country perspective. SEDME-small enterprises development", Management and Extension Journal), Vol. 46 No. 3, pp. 161-170, available at: https://doi.org/10.1177/ 0970846419871125

Shankar, V. and Narang, U. (2020), "Emerging market innovations: unique and differential drivers, practitioner implications, and research agenda", Journal of the Academy of Marketing Science, Vol. 48 No. 5, pp. 1030-1052.

World Bank (2020). "The world bank in Bangladesh: overview”, World Bank, available at: https:/www. worldbank.org/en/country/bangladesh/overview

\section{Further reading}

Keller, K.L. (2007), "Advertising and brand equity”, in Tellis, G.J. and Ambler, T. (Eds), Handbook of Advertising, pp. 54-70. 


\begin{tabular}{|c|c|c|c|c|c|}
\hline Model & $\mathrm{R}$ & R square & $\begin{array}{l}\text { summary } \\
\text { Adjusted R square }\end{array}$ & Std. error of the estimate & 205 \\
\hline $\begin{array}{l}1 \\
\text { Note: }\end{array}$ & $\begin{array}{l}0.674^{\mathrm{a}} \\
\text { rs: (cons }\end{array}$ & $\begin{array}{l}0.455 \\
\text { uational, brc }\end{array}$ & $\begin{array}{c}0.446 \\
\text { lity, characteristic }\end{array}$ & 0.57633 & $\begin{array}{r}\text { Table A1. } \\
\text { Model summary } \\
\text { table }\end{array}$ \\
\hline
\end{tabular}

\section{Appendix 2}

\begin{tabular}{|c|c|c|c|}
\hline Cronbach's alpha & Reliability statistics & $\mathrm{N}$ of items & Toble A? \\
\hline 0.902 & & 25 & Reliability \\
\hline
\end{tabular}

\section{Corresponding author}

Shamsul Huq Bin Shahriar can be contacted at: shahriarhuq002@gmail.com

For instructions on how to order reprints of this article, please visit our website: www.emeraldgrouppublishing.com/licensing/reprints.htm

Or contact us for further details: permissions@emeraldinsight.com 